\title{
The societal relevance of river restoration
}

\author{
$\underline{\text { Jutta Deffner }}^{1,2}$ and Peter Haase ${ }^{3,4}$
}

\begin{abstract}
The majority of studies on the ecological success of river restoration show improved morphological conditions, but a poor response of the biota. Because most river restoration projects are costly, a debate has started on the meaningfulness of such investments. Yet only a few studies have investigated the societal dimension of river restoration projects in detail. Therefore, the main aim of this study is to shed light on the social aspects of river restoration. Our empirical study consisted of two parts: (1) an explorative study conducted with 32 residents encountered at three restored river sections in Germany and (2) standardized telephone interviews with 760 residents living in the vicinity of 10 different restored river sections in three federal states. The survey covered questions including which activities local residents carry out at restored river sections, how they judge the nature experience, and how they perceive (negative) effects and costs. The restored river sections are perceived positively by $>80 \%$ of the respondents describing the respective section as near-natural and beautiful. In the view of the survey participants, both the ecosystem and residents profit highly from the restoration measure $(>90 \%)$, while the agricultural sector is not rated as a high profiteer ( $36 \%$, multiple answers were possible). In full awareness of the costs of restoration projects (approximately 400,000 Euros per river $\mathrm{km}$ ), $70 \%$ of the interviewees regard further restoration projects as useful and only $6 \%$ as not useful. The results show that river restorations are of great value and are held in high esteem by the population. Moreover, the interviewees considered the investments made by the public or sponsors to be predominantly useful. These results are highly valuable for water managers and politicians as the societal relevance of river restoration might be a key factor in the ongoing public and political discussion about river restoration.
\end{abstract}

Key Words: perception; restoration success; societal relevance; symbolic aspects; Water Framework Directive

\section{INTRODUCTION}

Over the past century, throughout nearly the entire world, streams and rivers have been heavily polluted and morphologically degraded by industrial, domestic, and agricultural sources, leading to significant declines in water quality, biodiversity, and ultimately water provision (Strayer and Dudgeon 2010). In response, different legal frameworks have been issued in recent decades, such as the U.S. Clean Water Act (US CWA) and the European Union Water Framework Directive (EU WFD). The creation of these legal frameworks can be seen as a turning point within water policy. The ecological status of rivers, including their biocenosis, plays an important role in legal river assessments. For example, in Europe, approximately $60 \%$ of all streams and rivers do not currently meet the standards for "good ecological status" as required by the EU WFD; the rate of failure to meet this standard ranges from $40 \%$ in Eastern Europe to $90 \%$ in Western Europe (Solheim et al. 2012). River restoration is regarded as a key measure to improve the ecological status of streams and rivers worldwide. Accordingly, river restoration in the present day is a billion-dollar business. In the U.S. alone, two to three billion dollars are spent on river restoration annually (Bronner et al. 2013). In Germany, average costs for restoring one kilometer of river length have been estimated at 400,000 Euros (Haase et al. 2013).

Although numerous studies have shown that river restoration measures can significantly lead to improvements in morphology, most studies have also reported that the response of biota to these measures is poor (Bernhardt et al. 2005, Palmer et al. 2010, Januschke et al. 2011, Haase et al. 2013, Pilotto et al. 2018). The reasons for these findings are numerous. For example, some rivers may still be polluted; source populations for the recolonization process may be missing from the adjacent surroundings (Sundermann et al. 2011); or, there may be insufficient time for recovery (Leps et al. 2016). In the context of the high costs of further restoration projects and eventual additional conflicts with landowners, municipalities, and recreation-seekers, it is important to not only further optimize restoration strategies and techniques and to consider the demands of legal frameworks (e.g., U.S. EPA 1972, EU WFD 2000), but to also take into consideration a broader perspective of potential benefits, e.g., societal relevance. This is particularly true given that discussions have begun among water authorities and scientists regarding how reasonable further restoration projects really are.

One rather neglected factor is the societal relevance of river restoration. We expect that within a common understanding of cultural landscapes, including natural elements (see Sauer 1963), restored rivers are more attractive than channelized ones, particularly for social and recreational activities such as hiking, walking, cycling, angling, swimming, or kayaking (Kondolf and Yang 2008). Although there are some studies of the societal impacts of restored rivers, societal needs and perceived benefits have not yet been sufficiently investigated.

As the existing literature on the societal aspects of restoration shows, there are different comprehensions as to what restoration actually is (Dufour and Piégay 2009). Most definitions only focus on ecological aspects (Bradshaw 1997, Jungwirth et al. 2002, Wohl et al. 2005) and others, like the World Wildlife Fund and International Union for Conservation of Nature (WWF and IUCN 2000) definition, include societal dimensions expressed by

${ }^{1}$ ISOE - Institute for Social-Ecological Research, Frankfurt, Germany, ${ }^{2}$ Senckenberg Biodiversity and Climate Research Center SBiK-F, Ecosystem Services and Climate, Frankfurt am Main, Germany, ${ }^{3}$ Senckenberg Research Institute and Natural History Museum Frankfurt, Department of River Ecology and Conservation, Gelnhausen, Germany, ${ }_{4}^{4}$ Faculty of Biology, University of Duisburg-Essen, Essen, Germany 
the term "human well-being." Additionally, many definitions of restoration include the fact that a river should be closer to its (near-) natural state after restoration than before (Gore 1985, NRC 1992, Bradshaw 1997), while others argue that restoration is not a natural force. Eden et al. (2000) claim that river restorations should be analyzed as "nature-cultures" because a restored river is always human-made and therefore not really natural (see also Dufour and Piégay 2009).

The linkages between the ecological effects of river restoration measures and the societal importance of these measures are not well represented in the scientific discourse. A literature review on the evaluation of the success of ecological restorations shows that only $3.5 \%$ of the surveyed literature included societal and economic attributes (Wortley et al. 2013). However, several studies were conducted on the residents' perceptions of river restoration measures. Important for our research is the example of Marttila et al. (2016). The authors investigated the effects of recent stream restoration on river ecosystem services and user group satisfaction in Finland. They examined societal and ecosystem changes as well as recreational opportunities in relation to local residents, fishing habits, and opportunities for recreational fishermen.

Buijs (2009), Åberg and Tapsell (2013), and Westling et al. (2014) present studies of longer-term public perceptions following river restoration measures. Westling et al. (2014) examined the influences on perception among local residents 14 years after river restoration measures in northern England by investigating the uses of the riverine environment, likes and dislikes, as well as aspirations for the future. Åberg and Tapsell (2013) carried out pre-, post- and long-term perception surveys on the societal benefits of river restoration in northeast England. They demonstrate the changes in people's perceptions and attitudes toward restoration over time by evaluating general satisfaction, attractiveness, wildlife, visits, and recreation. Schaich (2009) measures local residents' perceptions and support of floodplain restoration efforts in a peri-urban environment in Luxembourg to link them with the perceived threat to the floodplain, basic beliefs, lifestyle orientations, knowledge, and sociodemographic variables. He shows that support is strong and that opinions can be linked more strongly to basic beliefs, lifestyle concepts, and environmental behavior than to sociodemographic variables (Schaich 2009). Another aspect is highlighted by Buijs (2009). He studied the perceptions of local residents by focusing on opposition to river restoration in the Netherlands; he showed that modifications may be seen by residents as a "destruction of cultural heritage." Nevertheless, Buijs (2009) shows that most people support river restoration because the scenic values and recreational opportunities improve, even though attachment decreases. He emphasizes the importance of including aesthetics and local identity in the planning process. Fox et al. (2016) offer a study on the conflicts around river restoration in the U.S., stressing the political and cultural dimensions. Seidl and Stauffacher (2013:7085) examine differences among local residents in terms of their degrees of acceptance of river restoration in Switzerland; they examine environmental attitudes and the perception of river bank quality and acceptance, finding "that differences in the mindset and specific local culture play a role."

The majority of these papers conclude with recommendations for improving the planning process of river restorations to achieve a higher acceptance among residents. Other studies with this issue as their main focus are Kondolf and Yang (2008), who provide an overview of the societal and cultural dimensions of river restoration, including cultural preferences, public participation, human uses of urban waterways, and conflicts, with the goal of improving the planning process, thereby reaching higher acceptance of river restorations. Additionally, Bouni (2014) examines the extent to which the social scale should be integrated into the planning process of such measures to increase acceptance among residents. Other studies focus on the river restoration planning process itself. One example is Junker and Buchecker (2008a), who present a guideline for successful planning and socially acceptable river restoration. The authors present strategies for including local society in the planning processes of river restorations; they also present best practice models and a guideline for municipalities that are planning river restorations.

Another aspect of research focuses on the assessment of river restorations to determine when restoration efforts are successful and why. Woolsey et al. (2007) elaborated guidelines that include a set of indicators and specific objectives for assessing the success of a river restoration. Within the set of indicators, socioeconomic aspects are considered, e.g., project acceptance, variety of recreational opportunities, or aesthetic landscape value. Jähnig et al. (2011) summarize that the success of river restoration measures can be defined using widely different parameters: abiotic aspects, biotic aspects, and socioeconomic aspects, e.g., recreational value.

A number of papers have addressed the perceptions of local residents concerning river restoration measures (Åberg and Tapsell 2013, Wortley et al. 2013, Westling et al. 2014) but a view on restorations in general (not focused on specific measures) is missing, at least in Germany. Given that many studies have emphasized the importance of recognizing "local specialties" (Marttila et al. 2016), place-dependent historical relationships (Westling et al. 2014), and "regional identity, history, and personal experience" (Fox et al. 2016:97), it is important to conduct further research on the perception of river restoration in a socio-cultural context specifically. It seems that a deeper understanding of perceptions and attitudes toward restorations is needed to not only increase acceptance of restoration projects but to better understand societal relations to nature and to consider these relations during the planning stage of a restoration project. A detailed understanding of how residents generally assess and perceive river restorations is still lacking. The dimensions of societal aspects, including the physical-material sphere (landscape elements, topography, biological functions, etc.), and the symbolic-emotional one (values, emotions, symbolic meanings), have not yet been investigated in depth. However, it seems important to include these dimensions when dealing with the question of whether river restorations are worthwhile measures, both ecologically and socially, and not just in a socioeconomic way.

Our empirical study aims to take another step toward closing this gap. Our main questions were as follows: How and to what extent are the changes and impacts of river restorations (concerning landscapes and biodiversity) perceived and assessed by residents? The objectives of the study are to investigate and differentiate the material-physical and the symbolic-emotional attitudes and perceptions of river restorations by local residents. Here, we are 
particularly talking about the value of natural elements, the perception of usefulness for different, e.g., recreational, activities as well as the cost perception and attitudes regarding the usefulness and the benefitting spheres of restorations. Therefore, this study may provide further arguments for the importance of river restorations.

\section{METHODS}

With the distinction of material and symbolic aspects, we refer to the social science concept of lifestyles (Rössel and Otte 2011) that can explain how ideals and value orientations of social groups influence behavior. Based on Bourdieu's (1982) understanding, lifestyles are the connection of social situation, social practices, and individual values. They can be seen as group-specific forms of the conduct and interpretation of life. They are typical patterns of how everyday life is organized, identity, values, and ideals created, and sense given to things. Lifestyles influence behavior and action, e.g., in leisure activities. This is the point where the concept becomes relevant to our research and the abovementioned dualism of the material and symbolic sphere. The physical-material sphere (social structural situation as well as landscape and nature elements) and the symbolic sphere (attitudes, perceptions) have to be specifically operationalized in the empirical design to elucidate how river restorations are perceived and assessed by residents.

Accordingly, the terms "perceptions" and "attitudes" are understood in the tradition of social psychology (Crawford and Nowak 2013). Perception means the process of collecting and interpreting information that reflects the individual characteristics of a person. Attitudes are seen as the result of the assessment of the social and natural environment of individuals. Both material and symbolic aspects have influence on individual behavior and perception. With this understanding, generalized attitudes toward and perceptions of nature and landscape elements form the relation to the nature of society. Such landscape and nature elements can, for example, be changes created by river restoration measures. The theoretical foundation of Becker et al. (2011:77) defines societal relations to nature as "... historically and culturally specific patterns and practices of means by which societies attempt to materially regulate and culturally symbolize their various relationships to nature." Cultural landscapes can be described as part of such a relation. In our socio-empirical study we focus on the practices (behavior influenced by attitudes and perceptions) of actors (local residents) within this framework. From this we deducted the relevant categories and dimensions for the empirical social research.

To investigate people's perceptions and attitudes, a two-step empirical design was established. In general, we used an explorative design to investigate respondents' general views and the benefits they see from living near a restored river. Therefore, we focused on residents of the nearby villages and on passersby visiting restored sections of the river (Åberg and Tapsell 2013, Westling et al. 2014).

The first step was an explorative study using qualitative social research methods. The second step served to quantify the results.

\section{Site selection}

The study design focused on river restorations that were carried out at least five years prior to this study. This requirement was set to guarantee that the succession phase had been completed ( $\mathrm{Li}$ et al. 2016) and that the initial reconstruction work was no longer visible, which ensured that the projects had reached a sufficient degree of maturity.

Ten corresponding river restoration projects were chosen out of a database on river monitoring (Haase et al. 2013). This database covers 25 larger river restoration projects across Germany and provides information on the restoration measures that were conducted and the results of ecological quality class assessments. The selection criteria were the different sizes of the municipalities, restoration costs, the age of the restoration project, and stream type. The goal was to at least include a certain amount of variability found in restoration projects. In addition, the restored river sites needed to be accessible for passersby (at least by foot on a trail). Otherwise, in the authors' view, it would probably not have been possible for the interviewees to know about the restoration (see Table 1).

\section{Explorative study at three sites}

In the first step, three restored river sections and their surroundings in the wider Rhine-Main area of Germany were chosen as the sites of qualitative interviews. The selection was based on the following criteria: restoration completed at least five years ago, public and topographic accessibility of river section, and accessibility for interviewer. The selected projects are marked in Table 1.

The aim of the explorative study was to gain a deeper understanding of the perceptions and attitudes of residents and passersby toward the restoration measures and their influence on the area's quality and attractiveness. Residents are people living in a village next to the restored river; passersby are visitors who were passing by. The results gained from this inquiry were also used to develop adequate and understandable questions and items for the standardized survey (see below). In total, 32 interviews were conducted in May 2013; each interview lasted 15 to 20 minutes. In this part, we focused on residents and passersby who were actually using the landscape around the river because we assumed that they could provide the most insight into their views of the landscape and river (this was different in the standardized study). Thus, the sample was quoted and not randomized (Kromrey 2006). A variety of people walking by or visiting the surroundings were addressed, including walkers with or without dogs, bikers, runners, and skaters (from here on referred to as passersby). Interviewees were selected following a screening question to reach a fair distribution of age, gender, and type of outdoor activity at the river section. The interviewees were documented according to the guideline topics. The guideline comprised questions concerning restoration measures, perception of the river surroundings before (retrospective view) and after the restoration, assessment of the restoration measures, and perception of costs. The interviews were conducted by two interviewers, documented by notes and a digital voice file (as backup), and analyzed using qualitative content analysis techniques (e.g., Strauss and Corbin 1990, Mayring 2008). From a methodological viewpoint, the explorative study grounds the development of a user-friendly questionnaire with valid items and categories. 
Table 1. The 10 restoration projects used in the standardized study. (WFD = Water Framework Directive; EQC $=$ ecological quality classes based on benthic invertebrate, macrophyte, and fish samples; $1=$ high, $2=$ good, $3=$ moderate, $4=$ bad, $5=$ poor).

\begin{tabular}{|c|c|c|c|c|c|c|c|c|c|c|}
\hline River, municipality & $\begin{array}{c}\text { Eder, } \\
\text { Hatzfeld }\end{array}$ & $\begin{array}{c}\text { Gersprenz } \\
\text { Reinheim }\end{array}$ & $\begin{array}{c}\text { Nette, } \\
\text { Weißenthurm }\end{array}$ & $\begin{array}{c}\text { Nidda }^{*}, \\
\text { Bad Vilbel }\end{array}$ & $\begin{array}{c}\text { Rodau } \\
\text { Obertshausen }\end{array}$ & $\begin{array}{c}\text { Ruhr, } \\
\text { Arnsberg }\end{array}$ & $\begin{array}{l}\text { Rur, } \\
\text { Jülich }\end{array}$ & $\begin{array}{l}\text { Rur, } \\
\text { Linnich }\end{array}$ & $\begin{array}{l}\text { Schwalm, } \\
\text { Brüggen }\end{array}$ & $\begin{array}{l}\text { Wurm, Übach- } \\
\text { Palenberg }\end{array}$ \\
\hline \multicolumn{11}{|l|}{ Restoration } \\
\hline Stream type ${ }^{\dagger}$ & 9 & 19 & 9 & 9.2 & 19 & 9 & 9 & 17 & 12 & 17 \\
\hline Population of municipality & 3192 & 16,928 & 7791 & 32,238 & 24,179 & 78,000 & 32,983 & 13,452 & 15,789 & 24,744 \\
\hline Length $(\mathrm{m})$ & 850 & 1200 & 700 & 450 & 2000 & 3500 & 400 & 800 & 4300 & 500 \\
\hline Total Costs (thousands $€$ ) & 535 & 650 & 850 & 253 & 300 & 6200 & 825 & 3600 & 2600 & 800 \\
\hline Costs/500m (thousands $€$ ) & 315 & 271 & 607 & 281 & 75 & 885 & 1031 & 2250 & 302 & 800 \\
\hline Age (years) & 7 & 6 & 6 & 12 & 11 & 6 & 17 & 12 & 16 & 6 \\
\hline WFD EQC & 3 & 5 & 3 & 5 & 4 & 4 & 4 & 4 & 3 & 4 \\
\hline \multicolumn{11}{|l|}{ Restoration measures } \\
\hline $\begin{array}{l}\text { Improving water body } \\
\text { structure }\end{array}$ & $\mathrm{X}$ & $\mathrm{X}$ & $\mathrm{X}$ & $\mathrm{X}$ & $\mathrm{X}$ & $\mathrm{X}$ & $\mathrm{X}$ & $\mathrm{X}$ & $\mathrm{X}$ & $\mathrm{X}$ \\
\hline Flood protection & $\mathrm{X}$ & - & - & - & $\mathrm{X}$ & - & $\mathrm{X}$ & $\mathrm{X}$ & $\mathrm{X}$ & - \\
\hline $\begin{array}{l}\text { Re-establishment of } \\
\text { consistency }\end{array}$ & - & $\mathrm{X}$ & - & - & $X$ & - & - & - & $X$ & - \\
\hline Bottom raising & - & - & - & $\mathrm{X}$ & $\mathrm{X}$ & $\mathrm{X}$ & - & $\mathrm{X}$ & - & $\mathrm{X}$ \\
\hline Removing artificial shoring & $\mathrm{X}$ & $\mathrm{X}$ & $\mathrm{X}$ & $\mathrm{X}$ & $\mathrm{X}$ & $\mathrm{X}$ & $\mathrm{X}$ & $\mathrm{X}$ & $\mathrm{X}$ & $\mathrm{X}$ \\
\hline Creating a new watercourse & - & $\mathrm{X}$ & - & $\mathrm{X}$ & $\mathrm{X}$ & - & $\mathrm{X}$ & $\mathrm{X}$ & $\mathrm{X}$ & $\mathrm{X}$ \\
\hline Insertion of woody debris & - & $\mathrm{X}$ & - & - & $\mathrm{X}$ & $\mathrm{X}$ & - & - & - & - \\
\hline $\begin{array}{l}\text { Rebranching of } \\
\text { watercourse }\end{array}$ & - & - & - & - & $\mathrm{X}$ & $\mathrm{X}$ & $\mathrm{X}$ & $\mathrm{X}$ & - & $\mathrm{X}$ \\
\hline $\begin{array}{l}\text { Extensification of flood } \\
\text { plain area usage }\end{array}$ & - & $\mathrm{X}$ & $\mathrm{X}$ & $\mathrm{X}$ & - & - & $\mathrm{X}$ & $\mathrm{X}$ & $\mathrm{X}$ & - \\
\hline Reconnecting lakes & - & - & - & - & $\mathrm{X}$ & - & - & - & - & - \\
\hline New flow control & - & - & $\mathrm{X}$ & $\mathrm{X}$ & $\mathrm{X}$ & - & - & - & - & - \\
\hline Elongation of water body & - & $\mathrm{X}$ & $\mathrm{X}$ & $\mathrm{X}$ & $\mathrm{X}$ & - & $\mathrm{X}$ & $\mathrm{X}$ & $\mathrm{X}$ & $\mathrm{X}$ \\
\hline
\end{tabular}

\section{Standardized study at 10 sites}

In the second step, 10 restored river sections and their surroundings were chosen as the sites of standardized interviews (Table 1).

The aim of the standardized study was to identify and quantify the factors that influence valuation of and attitudes toward the restoration measures and to determine how the costs of these measures are perceived. This step involved the completion of a standardized survey with a total of 760 computer aided telephone interviews (CATI). The questions were derived from the topics that were revealed to be important in the qualitative inquiry.

The sample included 10 municipalities in the three federal states of Hesse, North Rhine-Westphalia, and Rhineland-Palatinate. In every municipality, 75 to 79 interviews were realized. The interviewees were chosen randomly, but it was necessary that they knew the river section (quoted sample). Only residents who knew the restored river sections and had at least visited the respective river section from time to time were questioned. The CATI lasted between five and eight minutes and was conducted by four survey operators. The survey took place in October/November 2013.

Each interviewee answered a questionnaire referring to the river restoration project in the vicinity of the chosen municipality. The questions addressed three main topics, which were based on the explorative study mentioned above:

1. Activities carried out at the river (knowledge of restoration, frequency of visits to the section, activities carried out at the river);
2. Perceptions of the restored river sections (assessment of the river by nine attributes; see Fig. 1), observation of wildlife, changes observed after the restoration (e.g., flow velocity) and benefits for nature and society (assessment of five benefitting sectors such as ecosystem, agriculture, tourism), assessment of restoration as a whole;

3. Perceived possible negative effects and costs (estimation of cost, items concerning perception of cost, items concerning assessment of further restorations).

Fig. 1. How would you describe the restored part of the respective waterbody $(n=760)$ ? Mulitple answers possible.

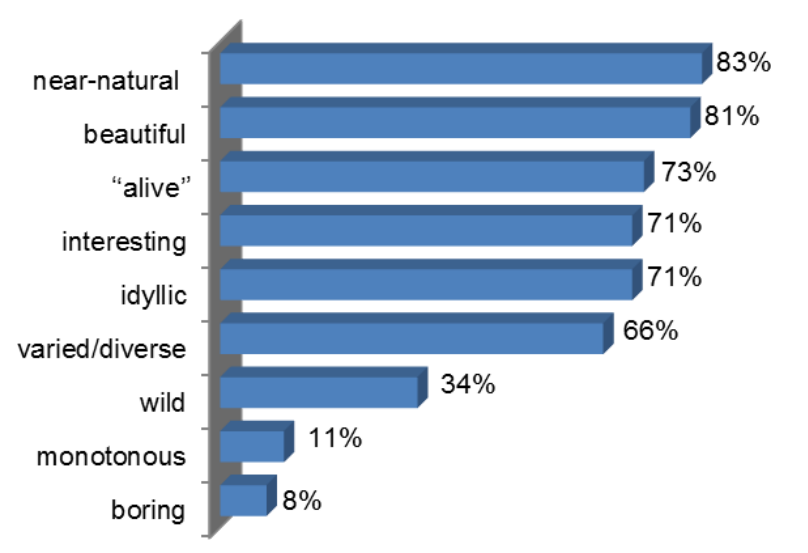


Finally, sociodemographic information on interviewees was gathered (age, household size, education, number of children under age 14 and dogs in household).

Different answer categories (e.g., ranging from 1 to 5) and items (e.g., given attributes describing the restored section) were provided so that interviewees could assess the river section and describe the impacts. The items were rotated to avoid answering biases as much as possible (Holbrook et al. 2007, Bogner and Landrock 2015). Because the interviewees could not estimate how much the restoration measures had cost (as we knew from the qualitative study), they were given information about the magnitude and the length of the restored river section before they had to answer whether they found the cost appropriate. For the analysis, a differentiation was made of study participants who actually knew the specific river section (connoisseurs) and the ones who never passed by the section (outsiders). Both surveys respected the privacy of the interviewees. The interviews were coded, and the categorization of answers was performed on an aggregated level.

\section{RESULTS}

\section{Activities carried out at the restored river}

The majority of interviewees $(85 \%)$ were aware that restoration measures had been conducted at their respective section of the river. A total of $82 \%$ had been visiting the restored section for more than 10 years and almost two-thirds for more than 20 years $(59 \%)$. Some residents $(18 \%)$ only came to know the river after restoration. When asked about the frequency of their visits to the river, $47 \%$ reported coming at least once per week, $24 \%$ visit it several times a month, and $23 \%$ several times a year. The majority of respondents visit the restored section to enjoy and observe nature, to walk, ride their bicycles, and to relax (Fig. 2).

Fig. 2. Activities carried out at the restored river sections $(\mathrm{n}=$ 760). Multiple answers possible.

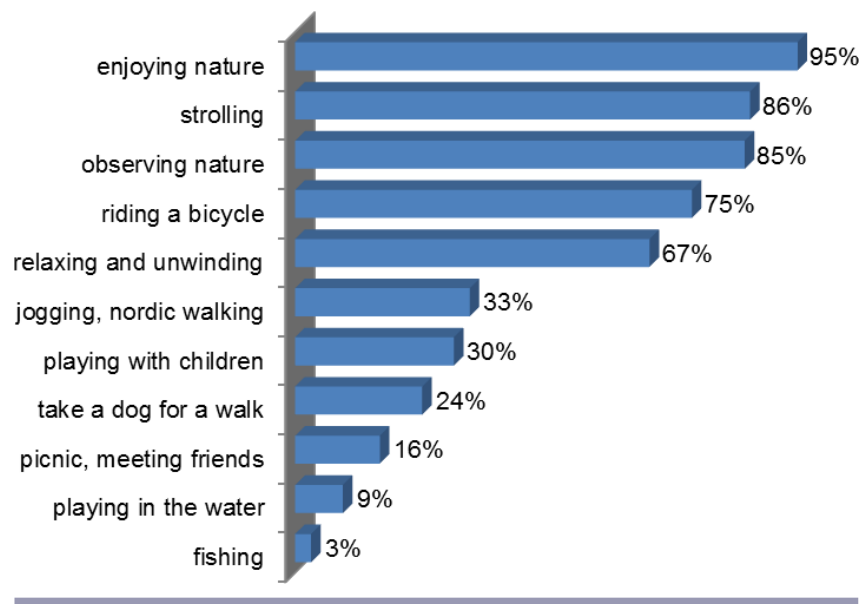

Perceptions of the restored river section and its benefits for nature and society

The majority of participants had positive perceptions of their respective river sections (Fig. 1; multiple answers were possible). In each case, more than $80 \%$ described the section as near-natural $(83 \%)$ and beautiful (81\%). More than $70 \%$ experience the river as "alive" (73\%), interesting (71\%), and idyllic (71\%), and more than $60 \%$ think it is diverse $(66 \%)$. A small group described it as boring $(8 \%)$ or monotonous (11\%), and about one-third thought the river is wild $(34 \%)$.

From the explorative study it became obvious that participants who knew the respective river section before restoration described the river before restoration as monotonous, boring, "dead straight," and "like a channel." Also, the diversity of flora and fauna was perceived to be lower. According to the interviewees, the flow velocity of the water was perceived to be faster before restoration than after. Additionally, the participants stated that the trails at some rivers were not well laid out and that lush vegetation sometimes obstructed the view of the river. In contrast, participants of the explorative part of the study emphasized the surroundings of the river after restoration as being diverse, harmonic, and beautiful. The landscape was perceived as natural or near-natural and as having largely recovered its original character. Some participants described the restored section as romantic and idyllic, or even "wild." Over the course of restoration, trail walks were redesigned and assessed positively. The visitors emphasized aspects of the good redesign: the water course was (more) varied and closer to pristine conditions because of meanders, paths made out of rocks or wooden trunks, and gravel- or sandbanks. The interviewees observed changes in flow velocity induced by, for example, the creation of additional river branches or an increase in river width. Some participants thought that the water contained more oxygen because of these measures. In addition, flood protection was assumed to be better after restoration than before.

The interviewees were asked to assess the benefits for nature (Fig. 3) and society (Fig. 4). The items were developed to address nature- as well as society-focused benefits. The benefits for both society and nature were described as having been improved through restoration: $75 \%$ think that linking recreation with ecology was successful. In the explorative study, the benefits to nature and society were described more in depth: "environmental protection is good for humans and ecology." Interviewees said that restoration measures are forward-looking because they can contribute to intergenerational equity, as the quote from one participant shows: "... nature for children and grandchildren." Additionally, restoration could be seen as a counterbalance to land consumption. Also, the quote of one participant shows the newly created value: "... a new ecosystem has come to life."

The residents who knew the river section before restoration (connoisseurs) assessed its status (in all aspects) better than residents who did not know the river section before restoration (outsiders). The benefits for society (Fig. 3) are, in general, rated higher than the benefits for nature (Fig. 4).

The majority of residents observed wildlife at the restored river section. The most observed animals were birds $(80 \%)$, insects such as dragonflies $(77 \%)$, fish $(61 \%)$, muskrats $(33 \%)$, and beavers $(23 \%)$. A total of $48 \%$ of the residents mentioned that they observed other animals as well. From the explorative study it became notable that interviewees mentioned detailed observations and knowledge about some species, even certain fish were mentioned. The vegetation was also perceived as more diverse than before restoration. 
Fig. 3. Agreed benefits for nature through restoration measures estimated by connoisseurs and outsiders $(n=760)$. Multiple answers possible. Scale with five categories from "total agreement" to "total disagreement." Agreed benefits = category 1 and 2 of scale.

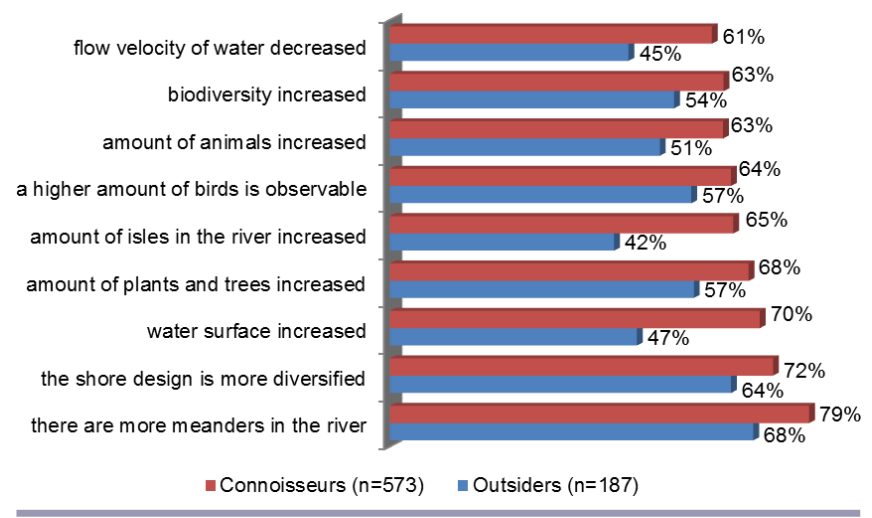

Fig. 4. Agreed benefits for society through restoration measures estimated by connoisseurs and outsiders $(n=760)$. Multiple answers possible. Scale with five categories from "total agreement" to "total disagreement." Agreed benefits = category 1 and 2 of scale.

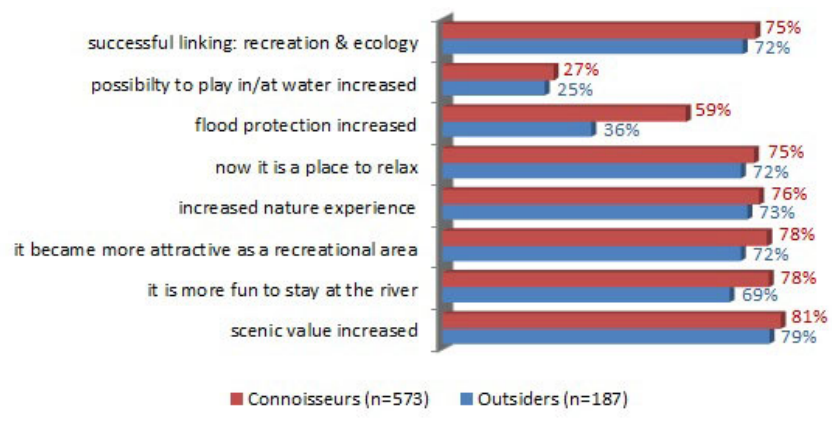

When asked about who actually profits from the restoration measures (Fig. 5), nearly all interviewees see the whole ecosystem $(96 \%)$, particularly plants $(95 \%)$ and animals $(94 \%)$, as beneficiaries of restoration measures. Society is also seen as a beneficiary $(90 \%)$. Corresponding with the qualitative results, only the tourism sector $(59 \%)$ and the agricultural sector $(36 \%)$ are not rated as benefitting substantially (multiple answers were possible). The explorative study gives insight into some details. Participants mentioned (on their own) that society benefits from restoration. In their view, the recreational value of the river had increased. For some, the river is sometimes the destination of a day trip. Families with children especially appreciate going to the restored river to play and swim. Some parts of the river are seen as a nature reserve, from which nature lovers and animal watchers particularly benefit.

\section{Perceived negative effects and costs}

A minority (10 to $16 \%$ ) of the comments cited negative effects of the restoration measures (multiple answers were possible): $10 \%$ thought that restoration was not necessary, $11 \%$ said the costs were too high, $11 \%$ did not think that the river was more beautiful after restoration, $11 \%$ did not know about the reasons for restoration at all, 13\% thought that the restored river section does not look natural, and $16 \%$ complained that they cannot directly reach the water anymore. Statements about the high costs of restoration measures showed a high variability among the different restoration sites.

Fig. 5. In your opinion, who profits from the restoration $(n=$ 760)? Multiple answers possible.

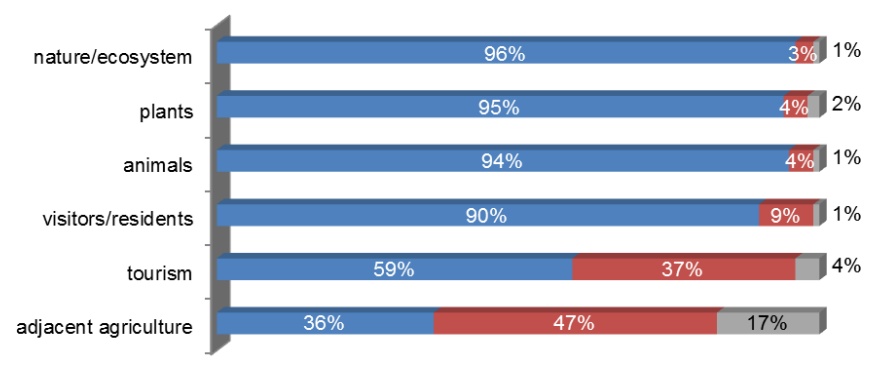

-Yes $=$ No $=$ Don't know

The explanations the participants of the explorative study gave show where the main doubts and critiques lie: some thought the measures were not successful because the landscape does not seem to be designed naturally but rather looks artificial. These people argued that nature should not be changed at all. Other interviewees assessed the restoration measures as questionable because they did not think that anyone benefits from restoration measures. In addition to other reasons, they thought that the costs of these measures were too high. Another group of participants complained about the density of vegetation, which hides the river from passersby. Other participants doubted whether the measures were really useful for flood protection. They also saw disadvantages for the agricultural sector because less acreage was available after restoration.

A little more than half of the interviewed residents thought that the costs for restoration measures were justified $(55 \%)$, one quarter were ambivalent (25\%), and 16\% thought that the costs were not justified at all; $4 \%$ had no opinion and did not answer the question. Acceptance of the costs varied considerably among the restored river sections: the lowest acceptance was found in Hatzfeld at the Eder River, where only $36 \%$ thought that the restoration costs were justified, and the highest acceptance was found in Obertshausen at the Rodau River, where $75 \%$ thought that the restoration costs were justified. In the exploration, possible explanations were mentioned by the interviewees: "First it should be clear what the profits of it are." This was unclear for the interviewee at a site where the surroundings of the river are rather rural and nearly natural. One other participant strongly requested public participation in the planning process.

\section{Overall assessment of the restoration measures}

The assessment was divided into two steps: the usefulness of restoration measures and the judgment of the costs. When respondents had full awareness of the costs of the respective restoration project, the overall assessment of the restoration measures was very positive: more than $80 \%$ think that the 
restoration measures were useful, and only $6 \%$ thought that these measures were not useful at all (very useful: $56 \%$, useful: $27 \%$, ambivalent: $11 \%$, not very useful: $3 \%$, not useful at all: $3 \%$ ). Regarding the appropriateness of the costs, the results show that, on average, only $11 \%$ rated the costs as too high. Yet, this value varied among the projects, from $4 \%$ to $23 \%$ (Fig. 6).

Fig. 6. Agreement to "costs of respective restoration project are too high" $(\mathrm{n}=760)$. Scale with five categories from "total agreement" to "total disagreement." Agreed benefits = category 1 and 2 of scale.

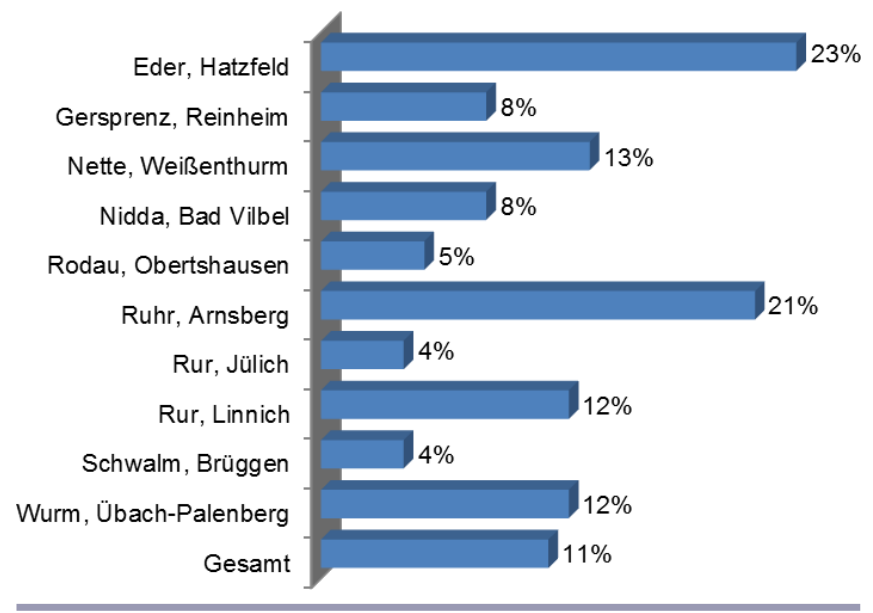

The variation in the perception of the costs is significantly driven by the age of the restoration project ( $p=0.031$; Table 2$)$. Older projects were rated better than younger projects. Other parameters such as length, total costs, costs per $500 \mathrm{~m}$, EQC (ecological quality class) of the restoration project, and population size of the municipality do not significantly correlate with the perception of "costs too high."

Further restoration measures were considered reasonable by $70 \%$ of the interviewees, and only $6 \%$ did not agree that further measures should be taken (see Fig. 7). Reasons given in detail in the explorative study were that restoration partially compensates for the overexploitation of nature, for example in the form of soil sealing. The costs of restoration were assessed as acceptable and as a good investment. Several participants thought the whole region would benefit economically from restoration measures because attractiveness for regional tourists would be increased.

Table 2. Spearman's rank correlation of "costs too high" with age, length, total costs, costs per $500 \mathrm{~m}$, ecological quality class (EQC) of the restoration project, and population size of the municipality. ${ }^{*} \mathrm{p}<0.05$.

\begin{tabular}{lcccccc}
\hline \hline & Age & Length & $\begin{array}{c}\text { Total } \\
\text { costs }\end{array}$ & Cost/500m & EQC & $\begin{array}{c}\text { Population } \\
\text { size }\end{array}$ \\
\hline $\begin{array}{l}\text { too high } \\
\text { costs }\end{array}$ & $-0.68^{*}$ & 0.04 & 0.17 & 0.28 & -0.25 & -0.31 \\
\hline
\end{tabular}

\section{DISCUSSION}

Differentiation of material-physical and symbolic-emotional aspects and attitudes regarding the usefulness and the benefitting spheres of restoration

To our knowledge, this is one of the only studies that investigates perceptions of river restoration projects by residents both qualitatively and quantitatively (Buijs 2009). Overall, the appreciation of the residents for the restoration projects shows that they have a general understanding of the importance of river restoration. Similar results can be observed in the studies of Schaich (2009), Buijs (2009), and Seidl and Stauffacher (2013). A different result, however, is reported by Fox et al. (2016) from the U.S. We interpret the rejection of restoration in this study as a general conflict around changes in cultural-historical landscapes and how people identify with landscapes. Such conflicts can also be observed in Germany following landscape changes because of wind energy plants (Roßnagel et al. 2016). The public discourse in the U.S. on landscape changes might also be driven by a different socio-cultural background. Even if the measures are connected to relatively high costs, broad acceptance is still given. This is in contrast to the results of the majority of ecological studies, which show that there are no or only minor effects of restoration measures on the recovery of species. This also applies to the 10 restoration projects in our study: none of them reached a "good" or "high" ecological status after restoration. These contradictory results between perception and ecosystem status may make sense because most restoration projects primarily improve the morphology of a river. Morphological improvements are often easily recognizable by residents, while these changes (alone) may not be sufficient to improve the biocenosis of a river. So the question might arise, do residents and passersby only have superficial or optimistic views on the improvements? A Swiss study found out that a favorable public assessment is consistent with good ecological quality (Junker and Buchecker (2008b).

Fig. 7. Acceptance of further restoration measures: Should there be further restoration of rivers in Germany with an average cost of $200.000 €$ per $500 \mathrm{~m}(\mathrm{n}=760)$ ?

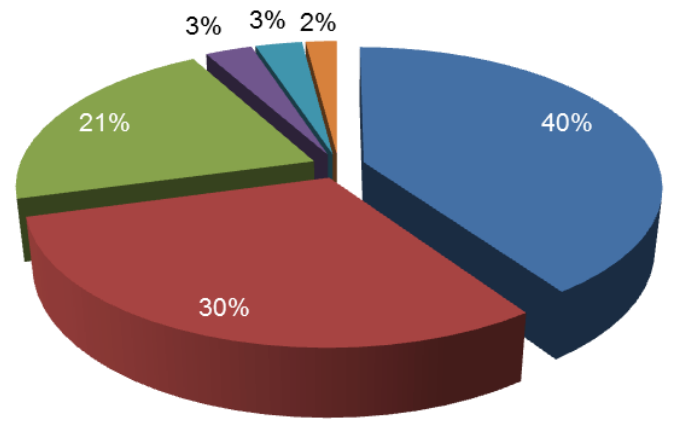

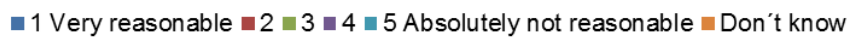

The restoration projects are valued as successful, attractive, and useful by most of the residents. The benefits observed are seen not only at a concrete material level, such as the river's actual usability as a recreational area or an improved fauna, but also at the level of symbolic value, such as the perception of the river as 
a scenic landscape, as a rebalancing of society and nature, or as a place that is fun to visit. This supports and exemplifies existing findings: Schaich (2009) argues that including human dimensions in restoration efforts and in landscape management is vital because the sustainability and the survival of the resulting "new landscapes" in the evolved cultural context depends, to a large extent, on public support. Åberg and Tapsell (2013) find clear long-term societal benefits of river restorations and show that attractiveness and affection for the area grow over time. To assess the success of river restoration, Schaich (2009) showed empirically that, compared with socio-demographic parameters, an individual's basic beliefs, lifestyle, and environmental behavior are more important determinants of his or her perceptions of floodplain restoration measures. This means that orientations such as, for instance, attitudes toward nature, views on life, leisure activities, or orientations such as traditionalism explain, better than income or age, how people value restorations. Our study contributes in-depth findings especially on how important symbolic aspects are for the perception of restorations. We have identified a variety of perceptions on landscape and identification therewith, on the expression of a society-nature balance, or on the aspect that restored rivers contribute to pleasure and subjective well-being.

The perception of usefulness for different (recreational) activities Another subject of discussion is the assessment of water-related leisure activities. Our study shows that bathing or playing in the water does not play a major role as a concrete use of the restored rivers. Therefore, we assume that there is no particular activity that should be prioritized by river restorations. Yet, this may depend on where the restored section is situated. As we know from our explorative study, families and dog owners explicitly appreciated opportunities for bathing and playing in the water at the Rodau River. It is not clear whether this is just a single case or if it might be of greater relevance in urbanized areas than in rural areas. We think that further research is needed to prove the extent to which spatial structures influence specific needs with regard to the recreational aspects of restoration measures.

We have also shown that the tourism sector is not seen by respondents as a major beneficiary of river restoration. Most of the rivers that were investigated are not in or near any tourism hotspot. Visitors are residents or people who come to the river as a local recreation area; some people visit it on day trips. Future restoration projects might consider how the recreational needs of the local population could be addressed.

The aspect of usability for recreational activities reflects the material dimension of river restorations and for the residents. It is also a contributing factor for the restoration to be a success. As discussed above, residents accept and value the broader necessity of river restoration for ecological reasons (benefitting spheres) but at the same time they want to have a practical individual benefit.

\section{Cost perception}

As a result of our qualitative study, it became clear that the estimation of restoration costs was difficult because most residents had no idea how expensive restoration projects were. When planning future measures, it may be worth considering how to find better ways of communicating costs and allowing residents and visitors to make comparisons. For example, what other measures for the public could be financed with this sum such as a children's playground or bike path? This could reduce the concerns of the small group $(11 \%)$ that named high costs as a negative effect of the measures and could appease those respondents who think that the costs are not justified $(16 \%)$. Here, results from other studies are helpful because they show how river restorations are either supported or criticized by residents.

In our study, we have shown that the perception of excessive costs of the respective restoration project is correlated with the age of the project. Because the costs of younger projects are viewed more critically (or are more present) than the costs of older projects, this might be linked to an ongoing succession process. Alternatively, residents might feel more familiar and attached (also shown in Åberg and Tapsell 2013) to an older project, leading to a less critical rating of the costs. Further studies with larger datasets are needed to clarify this issue.

Perceptions of costs might also be connected to other factors because there are general living conditions in a specific area or lifestyle orientations that might influence how people value, for example, landscapes, their restructuring, or public goods. With the first factor, that of living conditions, we propose that there could be strong interrelations with settlement structures and recreational outdoor possibilities for residents, all of which could be subsumed as pressure on recreational opportunities in the vicinity. One could hypothesize that in fairly rural areas, where the pressure on single landscape elements is not as high as in urbanized areas, the perception of river restorations and the appropriateness of costs are different. Yet, our data indicated no correlation between population size and appropriateness of costs.

The second factor, the influence of lifestyle orientations, has already been mentioned by Schaich (2009). His conclusion that these have more influence on perceptions than do sociodemographic characteristics is coherent with our observation that socio-demographic characteristics such as gender, household size, and education do not differentiate the results clearly. Even if we did not investigate lifestyle orientations in our survey directly, we can show that symbolic dimensions play a role in the assessment of restoration, as shown in the agreement with specific items: e.g., "more fun to stay at" or "place to relax." The overall high appreciation that residents expressed for the restoration includes symbolic and material aspects. In single cases, however, the results show that there might have been disputes about costs, the specific design of the restoration, and how it affects other land uses such as agriculture. The symbolic dimension of regional identity was not explicitly mentioned while in other studies (e.g., Seidl and Stauffacher 2013 or Fox et al. 2016) the contribution of the restoration to regional identity was emphasized.

Regarding costs, holding a public discussion in a village or a certain region is important because the majority of people want to know how public money is spent. This emphasizes the importance of public participation in planning (Seidl and Stauffacher 2013). Respondents pleaded for a participatory strategy with regard to river restoration in order to ensure public acceptance of the projects. Åberg and Tapsell (2013) and Marttila et al. (2016) also endorse a transparent process for rehabilitation schemes, as well as the provision of good information on restoration effects, to gain better support and more benefits. Other research has already been conducted to identify the relevance of participation when 
designing restoration measures (e.g., Junker and Buchecker $2008 a, b)$. We conclude that high availability of information and broad communication about reasons, effects, costs, and benefits increases acceptance and adoption by the local public. Summarizing the findings on the cost perception future restoration projects should respect the specific needs of ecological objectives and the local societal setting.

\section{Limitations}

The study's main limitation is the sample size. Because of limited funding, it was not possible to interview a larger proportion of residents at the restoration projects, especially in smaller municipalities. Therefore, a more detailed data analysis allowing for, e.g., findings on subgroups was not possible. Another limitation is the fact that for practical reasons and despite the operationalization of the framework of physical-material and symbolic-emotional dimensions of societal relations to nature, no other concepts like ecosystem services were used.

\section{CONCLUSIONS}

The often-reported poor biological response to restoration measures, in conjunction with the high costs of restoration projects, has already launched a political discussion. Yet, our study and others clearly show that restoration is of great value and is held in high esteem by the population living in close proximity to the restored rivers.

There is no clear line in the literature between ecological improvement and societal benefit (on the incongruence between aesthetic preferences and ecological quality, e.g., Nassauer 1993, Gobster 1994, Parsons 1995, van den Berg and Vlek 1998, Hands and Brown 2002, Williams and Cary 2002). Even so Junker and Buchecker (2008b) compared symbolic-aesthetic assessment by the public with ecological assessment made by experts (like Daniel 2001). They found that a favorable public assessment is consistent with good ecological quality. In contrast, our study showed that none of the investigated restoration projects reached a good or high ecological status as demanded by the EU WFD, while the overall perception of the restoration measures by the residents was nonetheless high. Given that the majority of studies of river restoration assessments report only minor improvements in ecological status, we believe that the current divergence between ecological improvement and societal benefit may apply to the many other projects. We also conclude that the current perspective on river quality is too narrow; a wider perspective on the river area or surroundings might be useful. This strengthens the argument that benefits and their importance cannot be observed separately for different spheres. Therefore, studies investigating the perceptions of people might add a new perspective to the discussion about future restoration projects. In addition, we conclude that our results emphasize the importance of a participative planning process that also includes the communication of costs. Yet, we also consider this as an important argument in favor of future river restoration projects because the restored river sections are highly appreciated and frequently visited by residents.

\section{Responses to this article can be read online at:} http://www.ecologyandsociety.org/issues/responses. $\mathrm{php} / 10530$

\section{Acknowledgments:}

The authors would like to thank Barbara Birzle-Harder, Mathias Kuemmerlen, Benjamin Kunkel, Stefanie Schwerdtfeger, and Andrea Sundermann for their help in realizing the paper. Our thanks include the colleagues at University Duisburg-Essen for helping to select the rivers out of the data base. We are also grateful to Nathan Baker for the language check. Without the frankness and time of the respondents, outdoors and on the telephone, this study would not have been possible: thank you to all study participants. We highly appreciate the funding of this study by the Kurt-Lange Stiftung, the Deutsche Bundesstiftung Umwelt, the Stiftung Hessischer Naturschutz, and the Stiftung der Kreissparkasse Gelnhausen.

\section{LITERATURE CITED}

Åberg, E. U., and S. Tapsell. 2013. Revisiting the River Skerne: the long-term social benefits of river rehabilitation. Landscape and Urban Planning 113:94-103. http://dx.doi.org/10.1016/j. landurbplan.2013.01.009

Becker, E., D. Hummel, and T. Jahn. 2011. Gesellschaftliche Naturverhältnisse als Rahmenkonzept. Pages 75-96 in M. Groß, editor. Handbuch Umweltsoziologie. VS Verlag für Sozialwissenschaften, Wiesbaden, Germany. http://dx.doi.org/10.1007/978-3-531-93097-8 4

Bernhardt, E. S., M. A. Palmer, J. D. Allan, G. Alexander, K. Barnas, S. Brooks, J. Carr, S. Clayton, C. Dahm, J. Follstad-Shah, D. Galat, S. Gloss, P. Goodwin, D. Hart, B. Hassett, R. Jenkinson, S. Katz, G. M. Kondolf, P. S. Lake, R. Lave, J. L. Meyer, T. K. O'Donnell, L. Pagano, B. Powell, and E. Sudduth. 2005. Synthesizing U.S. river restoration efforts. Science 308 (5722):636-637. http://dx.doi.org/10.1126/science.1109769

Bogner, K., and U. Landrock. 2015. Antworttendenzen. GESIS Survey Guidelines. GESIS - Leibniz Institut für Sozialwissenschaften, Mannheim, Germany. 10.15465/sdm-sg_016

Bouni, C. 2014. Designing ambitious projects for river restoration. Feedbacks from projects in Europe integrating the human and social sciences. ONEMA Knowledge for Action 10:1-28.

Bourdieu, P. 1982. Die feinen Unterschiede. Kritik der gesellschaftlichen Urteilskraft. Suhrkamp, Frankfurt am Main, Germany.

Bradshaw, A. D. 1997. What do we mean by restoration? Pages 8-14 in K. Urbanska, N. Webb, and P. Edwards, editors. Restoration ecology and sustainable development. Cambridge University Press, Cambridge, UK.

Bronner, C. E., A. M. Bartlett, S. L. Whiteway, D. C. Lambert, S. J. Bennett, and A. J. Rabideau. 2013. An assessment of U.S. stream compensatory mitigation policy: necessary changes to protect ecosystem functions and services. Journal of the American Water Resources Association 49:449-462. http://dx.doi.org/10.1111/ jawr.12034

Buijs, A. E. 2009. Public support for river restoration. A mixedmethod study into local residents' support for and framing of river management and ecological restoration in the Dutch floodplains. Journal of Environmental Management 90 (8):2680-2689. http://dx.doi.org/10.1016/j.jenvman.2009.02.006 
Crawford, L. A., and K. B. Novak. 2013. Individual and society: sociological social psychology. Routledge, New York, New York, USA. http://dx.doi.org/10.4324/9781315856520

Daniel, T. C. 2001. Aesthetic preference and ecological sustainability. Pages 15-29 in S. R. J. Sheppard and H. W. Harshaw, editors. Forests and landscape: linking ecology, sustainability and aesthetics. CABI, New York, New York, USA. http://dx.doi. org/10.1079/9780851995007.0015

Dufour, S., and H. Piégay. 2009. From the myth of a lost paradise to targeted river restoration: forget natural references and focus on human benefits. River Research and Applications 25 (5):568-581. http://dx.doi.org/10.1002/rra.1239

Eden, S., S. M. Tunstall, and S. M. Tapsell. 2000. Translating nature: river restoration as nature-culture. Environment and Planning D 18(2):257-273. http://dx.doi.org/10.1177/026377580001800201

European Union Water Framework Directive (EU WFD). 2000. European Union Water Framework Directive. European Commission, Brussels, Belgium. [online] URL: http://ec.europa. eu/environment/water/water-framework/

Fox, C. A., F. J. Magilligan, and C. S. Sneddon. 2016. "You kill the dam, you are killing a part of me": dam removal and the environmental politics of river restoration. Geoforum 70:93-104. http://dx.doi.org/10.1016/j.geoforum.2016.02.013

Gobster, P. H. 1994. The urban savanna reuniting ecological preference and function. Ecological Restoration 12(1):64-71. http://dx.doi.org/10.3368/er.12.1.64

Gore, J. A. 1985. The restoration of rivers and streams: theories and experience. Butterworth, Oxford, UK.

Haase, P., D. Hering, S. C. Jähnig, A. W. Lorenz, and A. Sundermann. 2013. The impact of hydromorphological restoration on river ecological status: a comparison of fish, benthic invertebrates, and macrophytes. Hydrobiologia 704 (1):475-488. http://dx.doi.org/10.1007/s10750-012-1255-1

Hands, D. E., and R. D. Brown. 2002. Enhancing visual preference of ecological rehabilitation sites. Landscape and Urban Planning 58(1):57-70. http://dx.doi.org/10.1016/S0169-2046(01) $\underline{00240-7}$

Holbrook, A. L., J. A. Krosnick, D. Moore, and R. Tourangeau. 2007. Response order effects in dichotomous categorical questions presented orally. The impact of question and respondent attributes. Public Opinion Quarterly 71(3):325-348. http://dx.doi.org/10.1093/poq/nfm024

Jähnig, S. C., A. W. Lorenz, D. Hering, C. Antons, A. Sundermann, E. Jedicke, and P. Haase. 2011. River restoration success: a question of perception. Ecological Applications 21 (6):2007-2015. http://dx.doi.org/10.1890/10-0618.1

Januschke, K., S. Brunzel, P. Haase, and D. Hering. 2011. Effects of stream restorations on riparian mesohabitats, vegetation and carabid beetles. Biodiversity and Conservation 20(13):3147-3164. http://dx.doi.org/10.1007/s10531-011-0119-8

Jungwirth, M., S. Muhar, and S. Schmutz. 2002. Re-establishing and assessing ecological integrity in riverine landscapes. Freshwater Biology 47(4):867-887. http://dx.doi.org/10.1046/ j.1365-2427.2002.00914.x
Junker, B., and M. Buchecker. 2008a. Aesthetic preferences versus ecological objectives in river restorations. Landscape and Urban Planning 85(3-4):141-154. http://dx.doi.org/10.1016/j. landurbplan.2007.11.002

Junker, B., and M. Buchecker. 2008b. Sozialverträgliche Flussrevitalisierungen: ein Leitfaden. Forschungsanstalt für Wald, Schnee und Landschaft WSL. Birmensdorf, Switzerland.

Kondolf, G. M., and C.-N. Yang. 2008. Planning river restoration projects: social and cultural dimensions. Pages 43-60 in S. Darby and D. Sear, editors. River restoration: managing the uncertainty in restoring physical habitat. John Wiley and Sons, Chichester, UK. http://dx.doi.org/10.1002/9780470867082.ch4

Kromrey, K. 2006. Empirische Sozialforschung. Modelle und Methoden der standardisierten Datenerhebung und Datenauswertung. Lucius \& Lucius Verlag, Stuttgart, Germany.

Leps, M., A. Sundermann, J. D. Tonkin, A. W. Lorenz, and P. Haase. 2016. Time is no healer: increasing restoration age does not lead to improved benthic invertebrate communities in restored river reaches. Science of the Total Environment 557-558:722-732. http://dx.doi.org/10.1016/j.scitotenv.2016.03.120

Li, F., S. Stoll, A. Sundermann, and P. Haase. 2016. A newly developed dispersal metric indicates the succession of benthic invertebrates in restored rivers. Science of the Total Environment 569-570:1570-1578. http://dx.doi.org/10.1016/j.scitotenv.2016.06.251

Marttila, M., K. Kyllönen, and T. P. Karjalainen. 2016. Social success of in-stream habitat improvement: from fisheries enhancement to the delivery of multiple ecosystem services. Ecology and Society 21(1):4. http://dx.doi.org/10.5751/ES-08118-210104

Mayring, P. 2008. Qualitative Inhaltsanalyse: Grundlagen und Techniken. 10. Auflage. Beltz, Weinheim, Germany

Nassauer, J. I. 1993. Ecological function and the perception of suburban residential landscapes. Pages 55-60 in P. H. Gobster, editor. Managing urban and high use recreation settings. General Technical Report. U.S. Forest Service North Central Forest Experiment Station, St. Paul, Minnesota, USA.

National Research Council (NRC). 1992. Restoration of aquatic ecosystems: science, technology, and public policy. The National Academies Press, Washington, D.C., USA. https://doi. org/10.17226/1807

Palmer, M. A., H. L. Menninger, and E. Bernhardt. 2010. River restoration, habitat heterogeneity and biodiversity: a failure of theory or practice? Freshwater Biology 55(S1):205-222. http://dx. doi.org/10.1111/j.1365-2427.2009.02372.X

Parsons, R. 1995. Conflict between ecological sustainability and environmental aesthetics: conundrum, canärd or curiosity. Landscape and Urban Planning 32(3):227-244. http://dx.doi. org/10.1016/0169-2046(95)07004-E

Pilotto, F., J. D. Tonkin, K. Januschke, A. W. Lorenz, J. Jourdan, A. Sundermann, D. Hering, S. Stoll, and P. Haase. 2018. Diverging response patterns of terrestrial and aquatic species to hydromorphological restoration. Conservation Biology. https:// doi.org/10.1111/cobi.13176 http://dx.doi.org/10.1111/cobi.13176 
Rössel, J., and G. Otte, editors. 2011. Lebensstilforschung. VS Verlag, Wiesbaden, Germany.

Roßnagel, A., B. Birzle-Harder, C. Ewen, K. Götz, A. Hentschel, A.-M. Horelt, A. Huge, and I. Stieß. 2016. Entscheidungen über dezentrale Energieanlagen in der Zivilgesellschaft. Vorschläge zur Verbesserung der Planungs- und Genehmigungsverfahren. Interdisciplinary Research on Climate Change Mitigation and Adaptation, Vol. 11. Kassel University Press, Kassel, Germany.

Sauer, C. O. 1963. The morphology of landscape. Pages 315-350 in J. Leighly, editor. Land and life: a selection from the writings of Carl Ortwin Sauer. University of California Press, Berkeley, California, USA.

Schaich, H. 2009. Local residents' perceptions of floodplain restoration measures in Luxembourg's Syr Valley. Landscape and Urban Planning 93(1):20-30. http://dx.doi.org/10.1016/j. landurbplan.2009.05.020

Seidl, R., and M. Stauffacher. 2013. Evaluation of river restoration by local residents. Water Resources Research 49 (10):7077-7087. http://dx.doi.org/10.1002/2013WR013988

Solheim, A. L., K. Austnes, P. Kristensen, M. Peterlin, V. Kodes, R. Collins, S. Semeradova, A. Künitzer, R. Filippi, and H. Prchalová. 2012. Ecological and chemical status and pressures in European waters. Thematic assessment for EEA Water 2012 Technical Report. European Topic Centre on Island, Coastal and Marine Waters, European Environment Agency, Copenhagen, Denmark.

Strauss, A., and J. Corbin. 1990. Basics of qualitative research: grounded theory procedures and techniques. Sage, Newbury Park, California, USA.

Strayer, D. L., and D. Dudgeon. 2010. Freshwater biodiversity conservation: recent progress and future challenges. Journal of the North American Benthological Society 29:344-358. http://dx. doi.org/10.1899/08-171.1

Sundermann, A., S. Stoll, and P. Haase. 2011. River restoration success depends on the species pool of the immediate surroundings. Ecological Applications 21(6):1962-1971. http://dx. doi.org/10.1890/10-0607.1

U.S. EPA (U.S. Environmental Protection Agency). 1972. Summary of the Clean Water Act 33 U.S.C. $\$ 1251$ et seq. U.S. EPA, Washington, D.C., USA. [online] URL: https://www.epa. gov/laws-regulations/summary-clean-water-act

Van den Berg, A. E., and C. A. J. Vlek. 1998. The influence of planned-change context on the evaluation of natural landscapes. Landscape and Urban Planning 43(1-3):1-10. http://dx.doi. org/10.1016/S0169-2046(98)00102-9

Westling, E. L., B. W. J. Surridge, L. Sharp, and D. N. Lerner. 2014. Making sense of landscape change: long-term perceptions among local residents following river restoration. Journal of Hydrology 519:2613-2623. http://dx.doi.org/10.1016/j.jhydrol.2014.09.029

Williams, K. J. H., and J. Cary. 2002. Landscape preferences, ecological quality, and biodiversity protection. Environment and Behavior 34(2):257-274. http://dx.doi.org/10.1177/0013916502034002006
Wohl, E., P. L. Angermeier, B. Bledsoe, G. M. Kondolf, L. MacDonnell, D. M. Merritt, M. A. Palmer, N. L. Poff, and D. Tarboton. 2005. River restoration. Water Resources Research 41 (10):W10301. http://dx.doi.org/10.1029/2005WR003985

Woolsey, S., F. Capelli, T. Gonser, E. Hoehn, M. Hostmann, B. Junker, A. Paetzold, C. Roulier, S. Schweizer, S. D. Tiegs, K. Tockner, C. Weber, and A. Peter. 2007. A strategy to assess river restoration success. Freshwater Biology 52(4):752-769. http://dx. doi.org/10.1111/j.1365-2427.2007.01740.x

World Wildlife Fund and International Union for Conservation of Nature (WWF and IUCN). 2000. Forest landscape restoration. WWF/IUCN first international workshop on forest restoration initiative Forests Reborn, 3-5 July, Segoiva, Spain. [online] URL: https://cmsdata.iucn.org/downloads/flr segovia.pdf

Wortley, L., J.-M. Hero, and M. Howes. 2013. Evaluating ecological restoration success: a review of the literature. Restoration Ecology 21(5):537-543. http://dx.doi.org/10.1111/ $\underline{\text { rec. } 12028}$ 
Appendix 1. Questionnaire used in the quantitative study (telephone interviews).

\title{
Perception of river restoration
}

\author{
Telephone Survey CATI
}

Questionnaire: Closed Questions

Duration: 5 to 8 minutes

Watercourse: N.N.

Good day,

We are currently conducting a telephone survey on behalf of the Senckenberg Museum in Frankfurt. The topic is the restoration of streams and rivers. We are especially interested in your opinion on a restoration project at the Nidda.

The interview takes about 5 to 8 minutes.

\section{Screening Questions}

a. Do you sometimes go to the Nidda in Dortelweil in your leisure time for example to cycle or go for a walk?

- Yes ( $\rightarrow$ follow with b) / no (end the interview)

b. The interview is specifically about the ...river section .... This section of the ... has been restored approximately 13 years ago. That means, as far as possible, the original unencumbered state of the ... has been restored.

Do you know this part of the river?

- $\quad$ yes ( $\rightarrow$ follow with Question 1 ) / No (end interview)

1. Did you know this part of the ... already before the restoration in the year 2000 ?

- Yes/No

\section{How often do you pass this part of the river?}

- A couple of times a week

- Once a week

- One to three times a month

- A couple of times a year

- Once a year or less

\section{Since how many years do you pass this part of the river?}

- Since less than a year

- Since one to less than 5 years

- Since 5 to less than 10 years

- Since 10 to 20 years

- More than 20 years 


\section{When you pass this river section, what are you doing there?}

$\rightarrow$ Multiple answers are possible, just answer with yes or no

- Go for a Walk

- Jogging/Nordic Walking

- Cycle

- Walk the dog

- Fishing

- Splash or bathe in the water

- Play with kids

- Observe the nature

- Enjoy the landscape

- Rest and Relax

- $\quad$ Meet up for picnic

\section{Did you know beforehand that the ... close to xy village is a restored section of the river?}

- a) I knew that $\rightarrow 6$ and 7 a

- b) I did not know that $\rightarrow 6$ and $7 b$

\section{How would you describe this restored part of river?}

I will read you a few adjectives. Please answer with a scale from 1 to 5.1 means "applies exactly" and 5 means "does not apply at all". With the numbers in between you can grade your opinion.

$\rightarrow$ Rotate

- Nice, beautiful

- Boring

- Interesting

- Diverse

- Monotonous

- Lively

- Near-natural

- Idyllic

- Wild

7. a. $\rightarrow$ to everyone from 5a: Please remember how it looked before the restoration. What has changed in your perception through this restoration? I will read you a few statements.

7. b. $\rightarrow$ to everyone from $5 \mathrm{~b}$ : What is different about this section compared to a not restored river section? I will read you a few statements.

Please answer again by means of the scale from 1 to 5.1 means "applies exactly" and 5 means "does not apply at all". With the numbers in between you can grade your opinion. If you can not judge it, say "I don't know".

\section{$\rightarrow$ Rotate!}

- The river has more windings and bends

- There are more islands in the river

- The shoreline is more divers due to sandbanks, stones or driftwood

- The landscape has been embellished

- The water surface has been enlarged 
- There are more animals ( $\rightarrow$ yes also question $7 c$ )

- You can observe more birds ( $\rightarrow$ yes also question $7 c$ )

- There are more plants and trees

- The biodiversity of animals and plants has grown

- The flood protection has improved

- The flow velocity of the river has decelerated

- It has become more attractive as a recreation area

- You can bathe or splash better in the water

- It is more fun to stay there

- You can experience the nature better

- The connection between recreation and ecology is successful

- You can find calmness and reflection here

7c) Which of the following animals have you seen there?

- Birds

- Fish

$\rightarrow$ Open question: which ones?

- Amphibians, e.g. frogs

- Insects, e.g. dragonflies

- Beaver

- Muskrat

- Others, which ones?

8. To everyone: Do you see any negative aspects of this restoration? To what extent do you agree with the following statements? Please answer again by means of the scale from 1 to 5.1 means "applies exactly" and 5 means "does not apply at all". With the numbers in between you can grade your opinion. If you can not judge it, say "I don't know".

$\rightarrow$ Rotate!

- The cost of restoration is too high

- Restoration is unnecessary

- I do not know what the restoration could be good for

- The river section was just as beautiful before

- The restored river section seems artificial and human made

- You can no longer get to the river

\section{Who do you think profits from this restoration?}

$\rightarrow \mathrm{Yes} / \mathrm{No} / \mathrm{I}$ don't know

$\rightarrow$ Rotate!

- The people who are spending time there

- The nature/the ecosystem as a whole

- The animals

- The plants

- The tourism

- The adjacent agriculture

- Others, which ones?

\section{All in all, how useful do you consider this restoration?}

Please reply with the scale from 1 to 5.1 means "very useful" and 5 means "not useful at all". With the numbers in between you can graduate your answer. If you can not judge it, say "I don't know". 
11. The restoration costs for this $450 \mathrm{~m}$ long section at the ... are about xy Euros. How justified do you consider these costs?

Please answer again with the help of the scale from 1 to 5.1 means "justified" and 5 means "not justified at all ". With the numbers in between you can graduate your answer. If you can not judge it, say "I don't know “.

12. Humans and nature are supposed to benefit from restoration measures in water bodies. But they also cause costs, on average about 200,000 Euros per $500 \mathrm{~m}$. Against this background we would like to know how useful you think would further restorations in other waters in Germany be?

Please reply again with the scale from 1 to 5.1 means "very meaningful" and 5 means "not at all useful". With the numbers in between you can graduate your answer. If you can not judge it, say "I don't know".

\section{Sex: Male/Female}

14. May I ask how old you are? Years old

\section{How many people live in your household?}

16. How many of these are children under the age of 14 ?

\section{Which is your highest school graduation?}

- Lower secondary education without graduation

- Lower secondary education with graduation

- Secondary School/O-Level

- High School Diploma/A-level

- University

Give thanks and end the interview 